Working Paper 2009:12

Department of Economics

Correcting Mistakes: Cognitive Dissonance and Political Attitudes in Sweden and the United States

Mikael Elinder 


\title{
Correcting Mistakes: Cognitive Dissonance and Political Attitudes in Sweden and the United States
}

\author{
Mikael Elinder* \\ Research Institute of Industrial Economics (IFN) and Uppsala University.
}

\begin{abstract}
Cognitive dissonance theory predicts that the act of voting makes people more positive toward the party or candidate they have voted for. Following Mullainathan and Washington (2009), I test this prediction by using exogenous variation in turnout provided by the voting age restriction. I improve on previous studies by investigating political attitudes, measured just before elections, when they are highly predictive of voting. In contrast to earlier studies I find no effect of voting on political attitudes. This result holds for a variety of political attitudes and for both Sweden and the United States.
\end{abstract}

Keywords: Cognitive dissonance, Voting, Elections, Political Attitudes

JEL codes: B59, C21, D72

Acknowledgements: I wish to thank Niclas Berggren, Sören Blomquist, Hans Grönqvist, Elly-Ann Johansson, Henrik Jordahl, Che-Yuan Liang, Eva Mörk, Tuomas Pekkarinen, Panu Poutvaara, Håkan Selin, and David Strömberg, as well as seminar participants at Uppsala University, and at the 2008 Ph.D. student Workshop in Public Economics, Uppsala, for valuable comments and suggestions. The Jan Wallander and Tom Hedelius Foundation is gratefully acknowledged for financial support.

*Address: Uppsala University, Department of Economics, Box 513, SE-75120 Uppsala, Sweden. Email address: mikael.elinder@nek.uu.se 


\section{Introduction}

Economists routinely assume that preferences are stable and determine people's behavior. In direct contrast, social psychologists suggest that behavior influences preferences and attitudes. ${ }^{1}$ Cognitive dissonance theory has emerged as the most prominent development along these lines. The theory has been suggested to provide important insights to many areas involving human behavior. ${ }^{2}$ The empirical support for the theory has, however, hitherto almost exclusively relied on psychological experiments, many of which have been heavily criticized by Chen (2008).

One prediction from cognitive dissonance theory is that the act of voting makes people more positive toward the party or candidate they have voted for, which suggests an effect also on how people vote in future elections. A few studies have found such an effect of voting on political attitudes (Beasley and Joslyn, 2001; Anderson et al., 2004; Mullainathan and Washington, 2009). These studies all measure effects on political attitudes long before an opportunity to vote. As a consequence they provide limited information about the relevance of cognitive dissonance theory to voting and elections, since there is no guarantee that the measured attitudes persist until the next election. If cognitive dissonance theory is of relevance to voting, the empirical evidence should at least support that political attitudes measured just before elections are biased toward the previously supported candidate or party.

This paper contributes to this literature by testing if the act of voting influences political attitudes - measured just before elections - when they are highly predictive of party and candidate choices. To this end I make use of data from the Swedish Election Studies complemented with data from The American National Election Studies. As in Mullainathan and Washington (2009), the effect on political attitudes is identified by making use of exogenous variation in turnout provided by the voting age restriction. In contrast to earlier studies, I find no effect on political attitudes. This indicates that cognitive dissonance theory may not be as relevant for voting as previous studies have indicated. This result holds for a variety of political attitudes and for data from both Sweden and the United States.

Mullainathan and Washington argue that if cognitive dissonance theory has bearing on voting, then it provides a new explanation for the incumbency advantage and thus a motivation for term limits. They also argue that high turnout could lead to inefficient electoral outcomes since a larger body of voters would then obtain biased attitudes toward candidates.

\footnotetext{
${ }^{1}$ While preferences are inherently unobservable, attitudes are herein viewed as observable, and are thus akin to stated preferences.

${ }^{2}$ For reviews see: Harmon-Jones and Mills (1999) and Cooper (2007).
} 
These arguments rely on the assumption that the effect of voting on political attitudes has repercussions for future voting behavior. The analysis in this paper shows that this is assumption is not supported by data, neither from Sweden, nor from the United States. Instead, it seems that by the time of the subsequent election, political attitudes are not significantly influenced by previous voting behavior.

The theory of cognitive dissonance was first spelled out by Festinger (1957). Applied to the context of voting, the mechanism at work could be described as follows. Consider a young person being eligible to vote for the first time. She wants to vote for the party (or candidate) that best serves her political interests. She collects information about the different parties and votes for the preferred party. After the election, new information becomes available. This information may or may not support her prior that she voted for the "right" party. If she voted for the "wrong" party, her action was dissonant with her intention and a discomforting feeling arises. She can reduce the unpleasant feeling of dissonance either by changing her actions or by changing her political cognitions ${ }^{3}$ so that the party she voted for still appears to be the best choice. But, when it comes to elections she typically has to wait several years before getting an opportunity to vote for another party. To relieve dissonance she may, therefore, instead change her political preferences or filter the available information in such a way that the chosen party appears to be better than it is. ${ }^{4}$ Akerlof and Dickens (1982: p. 309) summarize the mechanism at work as: “... persons who have made decisions tend to discard information that would suggest such decisions are in error because the cognition that the decision might be in error is in conflict with the cognition that ego is a smart person."

The relevant question is therefore if citizens tend to vote for the same party in subsequent elections, even when the circumstances have changed so that they otherwise had voted for another party, or if they behave more rationally and vote for a different party. ${ }^{6}$ Because of

\footnotetext{
${ }^{3}$ To quote Festinger (1957, p3) "By the term cognition, here and in the remainder of the book, I mean any knowledge, opinion, or belief about the environment, about oneself, or about one's behavior." The cognitions under study herein are political attitudes. Note also that the change of cognitions need not be conscious, but could just as well be a subconscious undertaking.

${ }^{4}$ It has also been suggested that to avoid the negative feelings caused by dissonant cognitions, people may change cognitions in advance of events that could question their choices. In the context of voting this would mean that voters become more positive to the chosen party, even if there is no information that questions their choice (Festinger, 1957).

${ }^{5}$ It should, however, be noted that the motivational mechanism for dissonance arousal is still under debate. For example, Aronson $(1968,1992)$ argue that dissonance arises when behavior conflict with one's view of oneself (typically but not necessarily as being smart, moral, honest, etc). Cooper and Fazio (1984) quite differently argue that dissonance arouses when behavior has aversive consequences for others.

${ }^{6}$ Although the original theory of cognitive dissonance acknowledge that dissonance can be reduced by changing behavior, this has been claimed to be less likely than changing attitudes (Cooper, 2007). Furthermore, it is when dissonance is reduced by changing attitudes that cognitive dissonance theory predicts interesting effects on voting.
} 
data limitations it is, however, difficult to perform direct tests of whether the act of voting influences party choice in future elections. We therefore have to assess the relevance of cognitive dissonance theory, to voting and elections, by its impact on political attitudes. As a consequence it is important that we investigate political attitudes as close as possible to the elections in which we really would have liked to investigate voting.

\section{Previous Literature and Methodological Considerations}

Empirical studies have suggested that cognitive dissonance theory provides fruitful insight to, for example, religious behavior (Festinger et al., 1964), protection against HIV (Stone et al., 1994), curing phobias (Cooper, 1980), effects of terror attacks (Masters, 2005), and to behavior among monkeys (Egan et al., 2008). In an influential article, Akerlof and Dickens (1982) argue that cognitive dissonance theory may have important implications also for a wide range of economic problems such as safety regulation, social security, innovation, marketing, and crime. Recently, cognitive dissonance theory has also been suggested to provide insights to the understanding of voting behavior and elections.

While providing interesting and appealing theoretical predictions-sometimes directly contrasting with predictions from rational choice theory - many empirical tests of cognitive dissonance theory suffer from severe methodological problems. As mentioned in the introduction, Chen (2008) criticizes much of the empirical tests of cognitive dissonance theory in what has been labeled "The Free Choice Paradigm". This line of research started with Brehm's (1956) experiment, in which subjects were asked to rate objects and were then given a choice between two of the objects to take home. After the choice, they were asked to again rate all of the objects. The chosen object were then found to be rated higher and the rejected object lower than in the initial stage. This finding has been interpreted as evidence of choice induced attitude change and support for the theory of cognitive dissonance. Chen, however, points out that all studies in this tradition may be plagued by a problem of measurement error in ratings and fail to recognize that the choice may contain additional information about the respondents' preferences. This critique casts considerable doubts on the value of the empirical support for cognitive dissonance theory, although its factual consequence has not yet been investigated.

When it comes to voting, Beasley and Joslyn (2001) claim that the act of voting influences attitudes toward the presidential candidates in the United States. Their evidence is based on a comparison of attitudes in the pre-election survey and the post-election survey of the 
American National Election Studies. They find that those who report having voted tend to have more polarized attitudes toward the President than those who report that they abstained. Anderson et al. (2004) use data from the British Election Studies and compare perceptions of national economic conditions before and after the 1997 election. They find that after the election citizens that voted for the incumbent have a more positive view of past economic conditions than they had before the election.

The analyses by both Beasley and Joslyn (2001) and Anderson et al. (2004) suffer from several methodological problems. First, they are directly hit by the critique by Chen (2008). Second, if information about the parties' achievements and the state of the economy becomes more cheaply available in the end of an election campaign, it would be no surprise if those who voted for the winner changed their attitudes in favor of the winner already before voting. ${ }^{7}$ The same argument applies to those who voted for the loser. This mechanism would produce results similar to what Anderson et al. and Beasley and Joslyn interpret as support for cognitive dissonance. Third, Mullainathan and Washington (2009) criticize the approach by Beasley and Joslyn with the argument that turnout is likely to be correlated with attitudes. Consequentially, that approach almost automatically generates results that Beasley and Joslyn interpret as evidence of cognitive dissonance mechanisms being at work, even without any effect of voting on attitudes. Finally, even if none of these objections would be applicable, we would still not know if the attitude change would last until the next election and thus have consequences for voting.

Mullainathan and Washington avoid the problems associated with using pre- and postelection comparisons. Instead they identify the causal effect of voting on political attitudes with the exogenous variation in turnout provided by the voting age restriction. They find that those who were eligible to vote in the previous U.S. presidential election and report themselves as affiliated with the President's party rate the President almost 10 percentage points higher compared with those who were ineligible to vote but also consider themselves as affiliated with the President's party. As a result they find support for cognitive dissonance theory in the context of U.S. presidential elections.

\footnotetext{
${ }^{7}$ To see this, suppose that there are two groups of voters A and B. Group A does not care about economic growth while group B does. Just before the election it becomes clear that the incumbent is responsible for low economic growth. Voters belonging to group A does not change their attitude toward the incumbent or the opposition, while members of group B become relatively more in favor of the opposition. As a consequence the probability that the opposition wins the election increases. When investigating political attitudes after the election, then if the opposition won, we will find that those who voted for the winner will have obtained a more negative view of past economic development.
} 
The research design applied by Mullainathan and Washington clearly takes the literature forward by credibly identifying a causal effect of voting on political attitudes. Nevertheless, some problems and limitations remain. As mentioned in the introduction we are not sure whether the change in attitudes persists until the next election. This is a critical condition for voting behavior to be biased in favor of the previously supported candidate.

In an extension to their main analysis, Mullainathan and Washington test if their results hold if political attitudes are measured just before the subsequent presidential election. Interestingly, that analysis lends no support for cognitive dissonance mechanisms being at work. They claim, however, that the results from this extension are too weak, due to small point estimates and large standard errors, to draw firm conclusions and call for more research on this matter - a call that is answered in this paper.

Low turnout in American elections provides a further limitation, since cognitive dissonance theory predicts that only those who actually have voted should change their attitudes. The fact that less than half of the interviewed respondents actually voted in the elections could therefore confound the results.

In this paper, I make use of a similar research design as in Mullainathan and Washington, with the important difference that attitudes are measured just before elections, so as to more credibly investigate if any repercussion on future voting is likely. Furthermore, I extend the analysis to an investigation of data from both Sweden and the United States. The Swedish Election Studies contain similar questions as the American National Election Studies. This allows for a reexamination of the relevance of cognitive dissonance on a new data set, with a minimum of deviations in the empirical methodology. By using Swedish data, I also avoid the problem with low turnout in American elections. Turnout among first time voters in Sweden is very high in international comparisons and vary between 79 and 89 percent for the time period of this study.

\section{The Swedish Political System}

A brief description of some key features of the Swedish political system follows. The Swedish Parliament (Riksdagen) is the country's legislative body and appoints the Prime Minister, who then selects ministers to form a government. Elections to the parliament were held every three years before 1994 and are held every four years since then. To be eligible to vote a citizen must be 18 years old on Election Day. Seats in parliament are allocated by proportional representation. 
The Social Democratic Party has been the largest party in Sweden during the entire timespan for this investigation, receiving between 36.4 and 45.7 percent of the votes. The Social Democratic Party has ruled as a minority government for most of the years since 1982 (19821991 and 1994-2006). Between 1976 and 1982 a centre-right coalition ${ }^{8}$ served two terms and between 1991 and 1994 another centre-right coalition ${ }^{9}$ served one term.

\section{Data}

The empirical analysis, mainly, uses data from the Swedish Election Studies. However, in an extension, data from the American National Election Studies are used for complementary analyses. Both data sets consist of individual-level survey data. In addition the Swedish data are supplemented with register data. ${ }^{10}$ Below follows a description of the Swedish Election Studies. ${ }^{11}$

\subsection{Swedish Election Studies}

A separate wave of the Swedish Election Studies has been conducted in connection with all major elections in Sweden since 1956. The later surveys consist of a larger number of questions, which limits the time-span for this analysis back to 1979 for attitudes toward the parties and the Prime Minister. In each wave about 3,000 respondents are interviewed, with oversampling of first time voters.

Turnout in Sweden is normally very high compared to other developed democracies with non-compulsory voting. From 1979 to 2002, turnout rates have varied between 81 and 94 percent. Table 1 displays turnout rates for first time, second time, and all eligible voters from 1979 to 2002 . As can be seen, the turnout rates are marginally lower for first and second time voters than for the electorate at large. A t-test for different turnout rates between first and second time voters does not reject that they are equal. The data come from the electoral register for the sample contained in the Swedish Election Studies. The higher the turnout

\footnotetext{
${ }^{8}$ Between 1976 and 1979, the coalition consisted of the Centre Party, the Liberal Party, and the Moderate Party (Conservatives). In 1978 Prime Minister Torbjörn Fälldin (the Centre Party) left his post as Prime Minister, when both the Centre Party and the Liberal Party left the government. Ola Ullsten (The Liberal Party) became Prime Minister until the election in 1979. In 1979, Fälldin again became Prime Minister with the same three parties represented in the government. He kept that post until 1982. Excluding the 1982 election from the analysis does not change the qualitative results.

${ }^{9}$ This time it consisted of The Moderate Party (Conservatives), with Prime Minister Carl Bildt, the Centre Party, the Liberal Party, and the Christian Democrats.

${ }^{10}$ Appendix A and B report detailed descriptions of all variables as well as descriptive statistics for the different samples used in the analyses

${ }^{11}$ As the data from the American National Election Studies is publicly available and extensively discussed elsewhere, I refer to http://www.electionstudies.org, for references and description of that data.
} 
rates, the better the prospects for testing if voting influences the political attitudes, since those who did not vote in the previous election are predicted not to change their attitudes. Clearly, turnout rates among young Swedish citizens are much higher than the average of 48 percent that Mullainathan and Washington report for the United States in their study.

\begin{tabular}{cccc} 
Table 1: Turnout & & \\
\hline & $\begin{array}{c}\text { 1st-time } \\
\text { eligible voters }\end{array}$ & $\begin{array}{c}\text { 2nd-time } \\
\text { eligible } \\
\text { voters }\end{array}$ & $\begin{array}{c}\text { All eligible } \\
\text { voters }\end{array}$ \\
\hline 1979 & 87 & 89 & 91 \\
1982 & 86 & 89 & 91 \\
1985 & 87 & 88 & 90 \\
1988 & 81 & 78 & 86 \\
1991 & 80 & 81 & 87 \\
1994 & 89 & 85 & 87 \\
1998 & 80 & 82 & 81 \\
2002 & 79 & 77 & 80 \\
\hline
\end{tabular}

Note: The numbers refer to the percentage of eligible voters that actually voted in the election, taken from the electoral register for the sample in the Swedish Election Studies, including non-respondents.

A key quality indicator of any survey is the response rate. The response rates in the Swedish Election Studies vary between 69 and 82 percent (1979-2002), which is almost 10 percentage points higher than in the American National Election Surveys. ${ }^{12}$ Non-response in the Swedish Election Studies have been found to be somewhat more common among women, low income earners, the old ( $>70$ years old $)^{13}$, and citizens born abroad. The biggest difference in response rates is found between voters and non-voters (Holmberg and Oscarsson, 2004). Table 2 displays response rates for first time, second time, and all eligible voters. The numbers in parenthesis shows the response rates conditional on voting. As can be seen the response rates are typically higher for first and second time voters than for the electorate at large. Although the response rates are somewhat higher for young voters than for the whole young electorate, the differences are small.

The variables used in the empirical analysis are discussed in section 5. Appendix A and B report detailed descriptions of all variables as well as descriptive statistics for the different samples used in the analyses.

\footnotetext{
${ }^{12}$ Between 1978 and 2000 the response rates in the American National Election Surveys varied between 59.8 and 74.0 percent.

${ }^{13}$ Respondents over 80 years old are not included in the surveys.
} 
Table 2: Response Rates (in percent)

\begin{tabular}{cccc}
\hline & $\begin{array}{c}\text { 1st-time } \\
\text { voters }\end{array}$ & $\begin{array}{c}\text { 2nd-time } \\
\text { voters }\end{array}$ & All voters \\
\hline 1979 & $83(83)$ & $80(82)$ & $77(80)$ \\
1982 & $85(88)$ & $85(85)$ & $79(82)$ \\
1985 & $81(84)$ & $83(85)$ & $75(78)$ \\
1988 & $84(87)$ & $78(83)$ & $72(76)$ \\
1991 & $83(87)$ & $84(87)$ & $74(77)$ \\
1994 & $84(85)$ & $83(84)$ & $79(82)$ \\
1998 & $93(93)$ & $82(85)$ & $80(85)$ \\
2002 & $71(72)$ & $68(75)$ & $69(74)$ \\
\hline
\end{tabular}

Note: Numbers in parenthesis are conditional on voting

\section{Empirical strategy}

To make the results from this analysis are as comparable as possible to the results in Mullainathan and Washington, I follow the methodology applied by them as closely as possible. The key difference is that attitudes now are measured just before elections. This means that citizens who experience dissonance because they have previously voted for the "wrong" party now have the opportunity to relieve dissonance, by voting for another party, close at hand. As Table 3 shows, attitudes toward the Prime Minister's party, as measured in the weeks before elections, are highly predictive of party choice. Very few of those who rate the Prime Minister's party in the lower categories, report to vote for that party. In the top categories, most of the respondents report to have voted for the Prime Minister's party. This pattern suggests that if we find an effect of voting on political attitudes then it is reasonable assume an effect on party choice as well. 
Table 3: The Relationship Between Pre-election Attitudes and Vote Choice.

\begin{tabular}{ccc}
\hline $\begin{array}{c}\text { Attitude } \\
\text { toward the } \\
\text { PM's party }\end{array}$ & $\begin{array}{c}\text { Voted for the PM's } \\
\text { party } \\
\text { (All voters) }\end{array}$ & $\begin{array}{c}\text { Voted for the PM's } \\
\text { party } \\
\text { (First-time voters) }\end{array}$ \\
\hline 0 (negative) & 0.2 & 0 \\
1 & 0.5 & 0 \\
2 & 1.2 & 4.4 \\
3 & 0.9 & 2.5 \\
4 & 1.1 & 2.9 \\
5 & 7.2 & 4.2 \\
6 & 10.8 & 3.2 \\
7 & 19.4 & 27.4 \\
8 & 47.6 & 41.3 \\
9 & 70.0 & 61.5 \\
10 (positive) & 87.1 & 65.4 \\
\hline
\end{tabular}

Note: Column 2 and 3 display the share of voters that voted for the PM's party within each attitude category.

Recall, that turnout among young citizens is much higher in Sweden than in the United States which takes us closer to the theory by not letting as many non-voters confound our estimates. The results are obtained by estimating variations of the following equation on pooled cross sections:

Attitude $_{i, t}=\beta(\text { Second })_{i, t}+\gamma(\text { Party })_{i, t}+\delta(\text { Second } \times \text { Party })_{i, t}+\boldsymbol{X}_{i, t}^{\prime} \theta+\varepsilon_{i, t}$

where subscript $\mathrm{i}$ and $\mathrm{t}$ denote that the variable takes individual and election specific values. Attitude, represents different attitudes in different specifications. In the main specification, it captures the respondent's attitude toward the party to which the incumbent Prime Minister belongs, measured in the weeks just before the elections. The reason why attitudes toward a party is chosen as the dependent variable, and not attitudes toward the Prime Minister, is that in Sweden, and other countries with a multiparty system, general elections are typically framed as a choice between parties rather than between candidates. To ensure that the results do not critically depend on this particular choice of dependent variable, other measures of political attitudes will be examined in subsection 6.3. Second is a dummy that takes the value one if the respondent was eligible to vote in the previous election and therefore now is eligible to vote for the second time and zero if the first election in which the respondent is eligible to vote. Party, takes the value one if the respondent is affiliated with the party of the incumbent. Second $\times$ Party is an interaction term between Second and Party. $\mathrm{X}^{\prime}$ is 
a row vector of socioeconomic control variables, which include interactions with a dummy variable taking the value one if the incumbent Prime Minister is from the Social Democratic Party to capture the fact that those variables could be predictive both of the support for the incumbent in general and of the support for different parties (for more details about the variables see Appendix A). ${ }^{14}$

The idea behind this set up is to test if voters that were eligible to vote in the previous election have more polarized attitudes toward the supported party just before the current election than those who were not eligible to vote in the previous election. The parameter of interest is $\delta$, which if it is positive supports that voting affects political attitudes. Those who voted for the winner when they were first time voters should have obtained more positive attitudes toward the incumbent when interviewed just before the next election than those who are about to vote for the same party for the first time. ${ }^{15}$

As the focus is on young voters and we want to rule out that aging is driving the results, I follow Mullainathan and Washington and restrict the sample to contain only first and second time voters that are close in age. This means that the respondents are between 19 and 23 years old. ${ }^{16}$ Furthermore, all regressions include a set of socioeconomic characteristics and interaction terms as well as year fixed effects. ${ }^{17}$

\section{Results}

\subsection{Main Results}

Table 4 displays the results obtained with Attitude toward the party of the Prime Minister as the dependent variable. This variable takes values between 0 and 10, where a higher number means that the respondent likes that party more. Since this question has been asked since 1979 , the time-period covered by this analysis is 1979 to $2002 .^{18}$

Only respondents aged 19 to 23 are included in the analysis. This limits the sample but is likely to produce estimates that are less vulnerable to potential bias stemming from age differences between first and second time voters than if the age span was wider. The

\footnotetext{
${ }^{14}$ This empirical strategy is applied also to the American data in section 6.4, and is adopted from Mullainathan and Washington.

${ }^{15}$ Note that if $\delta$ is positive, and $\beta$ is negative and have a smaller absolute value than $\delta$, then we have two-sided polarization. This means that second time voters that are not affiliated with the Prime Minister's party have changed their attitudes to be less positive toward the Prime Minister' party.

${ }^{16}$ Before 1998, 19-21 year old first time voters are included and 21-22 year old second time voters. In 1998 and 2002 the corresponding ages are 20-22 and 22-23. This change is a result of having elections every four years instead of every three years since 1994.

${ }^{17}$ The control variables are chosen to be as similar as possible to the ones used by Mullainathan and Washington.

${ }^{18}$ This closely corresponds to the sample period in Mullainathan and Washington, 1978-2000.
} 
estimated coefficient for the interaction term Second $\times$ Party $(-0.125)$ is negative, small and statistically insignificant. The coefficient for Second is slightly negative (-0.213) but statistically insignificant. Party is, as expected, statistically significant and positive (3.641). Most of the socioeconomic controls and interaction terms do not obtain statistically significant coefficients (reported in Appendix C, Table C1). These first results suggest that the act of voting does not have as long-lasting influence on political attitudes as to be of importance in the subsequent election. As a comparison, Mullainathan and Washington estimate $\delta$ to be 0.93 (rescaled to be comparable with the results here) when political attitudes are measured two years after each election.

Table 4: Basic Results for Sweden (1979-2002)

Dependent variable:

Attitude toward the party of the Prime Minister

\begin{tabular}{lcccc}
\hline & $(1)$ & $(2)$ & $(3)$ & $(4)$ \\
\hline Second x Party & -0.125 & -0.115 & -0.029 & -0.018 \\
$(\boldsymbol{\delta})$ & & & & \\
& $(0.345)$ & $(0.279)$ & $(0.350)$ & $(0.285)$ \\
Second $(\beta)$ & -0.213 & -0.144 & 0.078 & -0.107 \\
& $(0.250)$ & $(0.221)$ & $(0.348)$ & $(0.296)$ \\
Party $(\gamma)$ & $3.641^{* * *}$ & $3.812^{* * *}$ & $3.590^{* * *}$ & $3.741^{* * *}$ \\
& $(0.237)$ & $(0.197)$ & $(0.240)$ & $(0.201)$ \\
\hline Control variables & Yes & Yes & Yes & Yes \\
Interaction terms & Yes & Yes & Yes & Yes \\
Year fixed effects & Yes & Yes & Yes & Yes \\
Age controls & - & - & Yes- & Yes- \\
Age span & $19-22$ & $18-23$ & $19-22$ & $18-23$ \\
Observations & 556 & 847 & 556 & 847 \\
\hline
\end{tabular}

Notes: Robust standard errors clustered on individuals in parentheses.

$*$ significant at $10 \% ; * *$ significant at $5 \% ; * *$ significant at $1 \%$.

To examine if this difference is a coincidence or a robust feature of the data, small variations in the estimations are reported in column 2 to 4 . In column 2 the sample is extended to include all first and second time voters. In column 3 a linear control for age and the corresponding interaction term included; again with the sample restricted to respondents aged 19 to 23 . Column 4 presents a combination of the extensions in column 2 and 3. The results are rather stable. The coefficients of interest $(\delta)$ are never statistically significant and in all regressions close to zero. ${ }^{19}$

\footnotetext{
${ }^{19}$ Furthermore, excluding the election in 1979 when there had been a restructuring of the government does not change the qualitative results. The $\delta$ coefficient becomes even closer to zero.
} 


\subsection{Endogeneity of Party Identification}

An obvious critique against measuring party identification close to an election is that it may have changed since the last election. Mullainathan and Washington address this potential endogeneity problem by analyzing if those who were eligible to vote in the previous election are more likely to have extreme attitudes toward the President, than those who were not eligible. That test does not make use of the party variable and show that their results are not driven by endogeneity of the party affiliation variable. This endogeneity problem could be more problematic in the present analysis because of the longer time span between the last election and the interview. As a robustness test, I have therefore performed an identical test. It indicates that the results presented in this section are not driven by endogeneity of the party identification variable, since second time voters are no more likely to have extreme attitudes than first time voters. ${ }^{20}$

\subsection{Alternative measures of political attitudes}

So far we have only analyzed attitudes toward the Prime Minister's party. Before we draw too strong conclusions, it would be illuminating too see if the same result is found when alternative political attitudes are analyzed. To show that the discrepancy between their findings and the findings herein is not stemming from a particular choice of political attitudes, four alternative attitudes are analyzed below. These are similar to the attitudes analyzed by Mullainathan and Washington. Table 5 presents the results from this exercise. In the first column attitudes toward the Prime Minister is used as dependent variable. This variable takes values between 0 and 10, were 10 means that the respondent likes the Prime Minister very much. Column 2 to 4 show the results obtained when specific characteristics of the Prime Minister are analyzed. The three variables measure how much the respondent agrees with the statement that the Prime Minister is Knowledgeable, Inspiring, and Likable. The variables can take values between 1 and 4 , were 4 means that the respondent completely agrees, and 1 means that the respondent strongly disagrees, with the statement. Since these questions have been asked in connection with four and two elections only, the sample sizes are relatively small. For that reason all first and second time voters are included in the regressions when Likable is used as dependent variable.

\footnotetext{
${ }^{20}$ The test is performed by estimating a logit model of Second on having extreme attitudes. The dependent variable is a dummy variable taking the value one if the respondent has an attitudes toward the Prime Minister's party that lies outside one standard deviation of the mean and zero otherwise. The estimated coefficient of eligible is -0.09 and the cluster robust standard errors are 0.16 .
} 
Table 5: Alternative Attitudes

\begin{tabular}{lcccc}
\hline $\begin{array}{l}\text { Dependent } \\
\text { variable: }\end{array}$ & $\begin{array}{c}\text { Prime } \\
\text { Minister }\end{array}$ & $\begin{array}{c}\text { PM } \\
\text { Knowledgeable }\end{array}$ & $\begin{array}{c}\text { PM } \\
\text { Inspiring }\end{array}$ & $\begin{array}{c}\text { PM } \\
\text { Likable }\end{array}$ \\
\hline $\begin{array}{l}\text { Second x Party } \\
(\boldsymbol{\delta})\end{array}$ & -0.336 & 0.081 & 0.333 & -0.071 \\
& & & & \\
Second $(\beta)$ & $(0.446)$ & $(0.150)$ & $(0.203)$ & $(0.189)$ \\
& -0.272 & -0.029 & $-0.215^{* *}$ & $-0.244^{*}$ \\
Party $(\gamma)$ & $(0.266)$ & $(0.097)$ & $(0.103)$ & $(0.139)$ \\
& $2.695^{* * *}$ & $0.212^{* *}$ & $0.354^{* * *}$ & $0.554^{* * *}$ \\
Control & $(0.278)$ & $(0.104)$ & $(0.122)$ & $(0.128)$ \\
variables & Yes & Yes & Yes & Yes \\
Year fixed & Yes & & & \\
effects & & Yes & Yes & Yes \\
Time Span & $1979-$ & $1988,91,98$, & 1988,91, & 1998, \\
& 2002 & 2002 & 98,2002 & 2002 \\
Age span & $19-22$ & $19-22$ & $19-22$ & $18-25$ \\
Observations & 554 & 282 & 284 & 217 \\
Adjusted R2 & 0.84 & 0.96 & 0.90 & 0.93 \\
\hline Notes: Robust stand & & & & \\
\hline
\end{tabular}

Notes: Robust standard errors clustered on individuals in parentheses.

$*$ significant at $10 \% ; * *$ significant at $5 \% ; * * *$ significant at $1 \%$.

As can be seen in Table 5, attitude change induced by voting is not found for any of the four alternative attitudes. In fact, the results are similar to the ones obtained in section 6.1. The parameter of interest is never significantly different from zero and two of the coefficients take negative values. As a consequence we can conclude that when attitudes are measured just before elections we do not find evidence of the kind of polarization we would expect if the act of voting by itself had long term effects on political attitudes. If we would see that attitudes were influenced by the act of voting, in the direction predicted by cognitive dissonance theory, then it would be reasonable to assume that voters tended to stick with their vote. This seems, however, not to be the case - at least not for Swedish voters.

Due to data limitations we, we have unfortunately not been able to investigate whether any attitude change consistent with cognitive dissonance theory is present two years after elections in Sweden. In presidential elections in the United States, citizens vote for persons rather than parties and turnout is much lower than in Sweden. Both of these aspects may point to that the act of voting is a stronger commitment in the United States than in Sweden. It is possible that this could imply that attitude changes are stronger in the United States and that results from Sweden cannot be generalized to the United States. However, if cognitive dissonance induced attitude change is present at any other time than just before elections is of 
second order importance. Our main interest is in attitudes just prior to elections - attitudes that determine voting. We, therefore, now turn to see whether similar results are found when we extend the analysis to American data.

\subsection{A Further Investigation of American Data}

Mullainathan and Washington present evidence of attitude change two years after elections, but find either very small or non-existent attitude change at the time of the subsequent election. They perform an extensive robustness analysis for political attitudes two years after the election, including an analysis of a wide range of attitudes, but do no such robustness analysis for attitudes measured close to the subsequent election.

So far we have seen that the "no effect" results are a robust feature of the Swedish data. It would be illuminating to investigate if the "no effects" results obtained by Mullainathan and Washington, when attitudes are measured just before elections, are a robust feature of the U.S. data as well. If so, it would further strengthen the evidence against long term attitude change arising from cognitive dissonance mechanisms. For descriptive statistics of the data in this section, see Appendix B.

Column 1 in Table 6 is a replication of the results in column 1 of Table 10 in Mullainathan and Washington. ${ }^{21}$ The dependent variable is a "thermometer" measuring the respondents' feelings toward the President on a scale from 0 to 100, were 100 indicates that the respondent likes the President the most. In column 1, feelings toward the President are analyzed for all elections between 1980 and 2000. In column 2, the age span has been increased to include 19to 25-year-olds. In column 3, controls for age have been added. Finally, in column 4, the age span has been increased and the controls for age have been added. The coefficient of interest is small in all of the specifications and not statistically significantly different from zero. In fact, the effect is reduced by about 80 percent, as compared with two years after elections. ${ }^{22}$

\footnotetext{
${ }^{21}$ The results differ somewhat from what Mullainathan and Washington report. Their $\delta=0.144$ (statistically insignificant). This difference is likely to be caused by a small difference in the number of observations. They report 630 observations. When I use their reported specification and a do-file provided by them, I obtain 632 observations.

${ }^{22}$ Their estimate of $\delta$ is 9.3 two years after elections.
} 
Table 6: Robustness Analysis for the American Case (1980-2000)

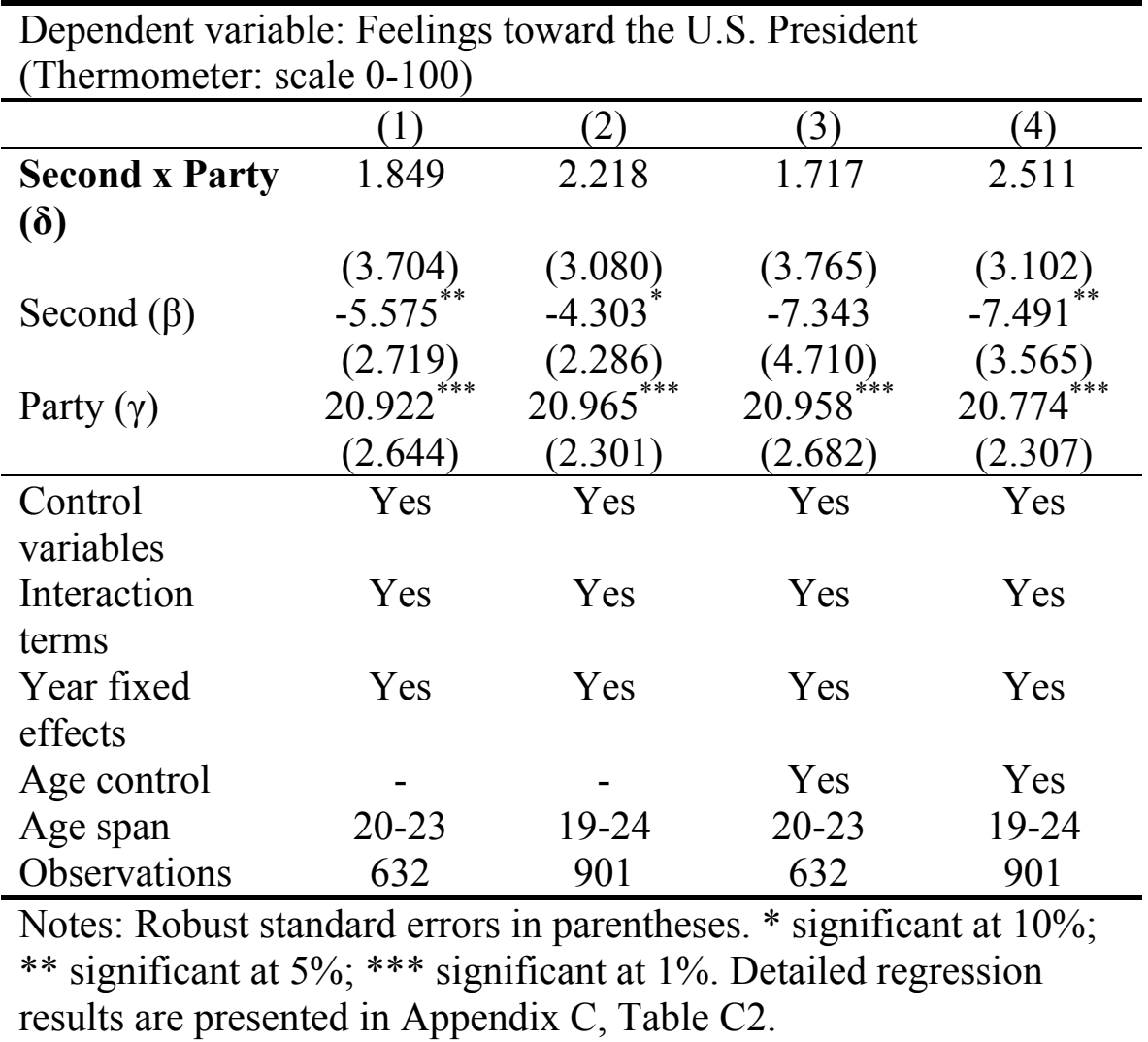

As a further robustness check, Table 7 shows the results when the full set of alternative political attitudes, that Mullainathan and Washington analyze two years after elections, is instead analyzed close to the subsequent election. While some of the coefficients of interest are positive, most of them are negative (all attitudes are rescaled so that a higher number corresponds to a more positive attitude). Furthermore, most of the coefficients are small and, except for Hopeful, none of them are statistically significantly larger than zero. Consequentially, we can conclude that there is no evidence of attitude change consistent with the prediction from cognitive dissonance theory - neither in Sweden nor in the United States when we analyze attitudes close to elections. 
Table 7: Alternative Attitudes -The American Case (1980-2000)

\begin{tabular}{|c|c|c|c|c|c|c|}
\hline \multirow[t]{2}{*}{ Dep. Var. } & \multicolumn{5}{|c|}{ Is the President...? (4 pt scale) } & \multirow{2}{*}{$\begin{array}{l}\text { Approval } \\
2 \text { pt scale }\end{array}$} \\
\hline & Inspiring & $\begin{array}{l}\text { Know- } \\
\text { ledgeable }\end{array}$ & Moral & $\begin{array}{l}\text { Good } \\
\text { leader }\end{array}$ & Caring & \\
\hline Second $x$ Party $(\delta)$ & $\begin{array}{l}-0.05 \\
(0.15)\end{array}$ & $\begin{array}{l}-0.24^{*} \\
(0.12)\end{array}$ & $\begin{array}{l}-0.07 \\
(0.14)\end{array}$ & $\begin{array}{l}-0.19 \\
(0.14)\end{array}$ & $\begin{array}{l}-0.05 \\
(0.15)\end{array}$ & $\begin{array}{l}-0.02 \\
(0.07)\end{array}$ \\
\hline Second $(\beta)$ & $\begin{array}{l}-0.11 \\
(0.10)\end{array}$ & $\begin{array}{c}0.04 \\
(0.09)\end{array}$ & $\begin{array}{c}0.05 \\
(0.10)\end{array}$ & $\begin{array}{c}0.15 \\
(0.10)\end{array}$ & $\begin{array}{l}-0.04 \\
(0.11)\end{array}$ & $\begin{array}{l}-0.03 \\
(0.06)\end{array}$ \\
\hline Party $(\gamma)$ & $\begin{array}{l}0.60^{* * *} \\
(0.11)\end{array}$ & $\begin{array}{l}0.52^{* * *} \\
(0.09)\end{array}$ & $\begin{array}{l}0.44^{* * *} \\
(0.10)\end{array}$ & $\begin{array}{l}0.59^{* * *} \\
(0.11)\end{array}$ & $\begin{array}{l}0.67^{* * *} \\
(0.12)\end{array}$ & $\begin{array}{l}0.37^{* * *} \\
(0.05)\end{array}$ \\
\hline Control variables & Yes & Yes & Yes & Yes & Yes & Yes \\
\hline Interaction terms & Yes & Yes & Yes & Yes & Yes & Yes \\
\hline Year fixed effects & Yes & Yes & Yes & Yes & Yes & Yes \\
\hline Observations & 559 & 611 & 603 & 612 & 491 & 613 \\
\hline \multirow[t]{2}{*}{ Dep. Var. } & \multicolumn{4}{|c|}{$\begin{array}{l}\text { Does the President make you...? } \\
\text { ( } 2 \mathrm{pt} \mathrm{scale)})\end{array}$} & \multirow[t]{2}{*}{$\begin{array}{l}\text { Approval } \\
4 \text { pt scale }\end{array}$} & \multirow{2}{*}{$\begin{array}{c}\text { Handling of } \\
\text { the } \\
\text { economy }\end{array}$} \\
\hline & Angry & Afraid & Hopeful & Proud & & \\
\hline Second $x$ Party $(\delta)$ & $\begin{array}{l}-0.02 \\
(0.08)\end{array}$ & $\begin{array}{c}0.06 \\
(0.08)\end{array}$ & $\begin{array}{l}0.14^{*} \\
(0.08)\end{array}$ & $\begin{array}{l}-0.06 \\
(0.08)\end{array}$ & $\begin{array}{l}-0.05 \\
(0.16)\end{array}$ & $\begin{array}{l}-0.05 \\
(0.26)\end{array}$ \\
\hline Second $(\beta)$ & $\begin{array}{c}0.04 \\
(0.06)\end{array}$ & $\begin{array}{l}-0.06 \\
(0.05)\end{array}$ & $\begin{array}{l}-0.10^{*} \\
(0.06)\end{array}$ & $\begin{array}{c}0.01 \\
(0.06)\end{array}$ & $\begin{array}{l}-0.05 \\
(0.11)\end{array}$ & $\begin{array}{c}0.11 \\
(0.18)\end{array}$ \\
\hline Party $(\gamma)$ & $\begin{array}{l}0.22^{* * *} \\
(0.06)\end{array}$ & $\begin{array}{l}0.15^{* * *} \\
(0.06)\end{array}$ & $\begin{array}{l}0.25^{* * *} \\
(0.06)\end{array}$ & $\begin{array}{l}0.30^{* * *} \\
(0.06)\end{array}$ & $\begin{array}{l}0.85^{* * *} \\
(0.12)\end{array}$ & $\begin{array}{l}1.07^{* * *} \\
(0.19)\end{array}$ \\
\hline Control variables & Yes & Yes & Yes & Yes & Yes & Yes \\
\hline Interaction terms & Yes & Yes & Yes & Yes & Yes & Yes \\
\hline Year fixed effects & Yes & Yes & Yes & Yes & Yes & Yes \\
\hline Observations & 615 & 616 & 614 & 615 & 612 & 491 \\
\hline
\end{tabular}

Notes: The dependent variables are recoded so that higher number refers to more positive attitudes. Robust standard errors in parentheses. $*$ significant at $10 \%$; ** significant at $5 \%$; $* * *$ significant at $1 \%$. 


\subsection{Direct Effects on Voting Behavior}

The investigation has so far implicitly assumed that the act of voting affects future voting only through political attitudes. Clearly, this assumption is questionable, as other channels may be missing. It could therefore be illuminating to test if the act of voting has a direct effect on future party choice.

Mullainathan and Washington perform such a test and finds an effect of previous voting of about two percentage points $(\delta=0.02)$. The effect is not statistically significant and the confidence interval indicates that both a large negative and a large positive effect are plausible. The power of this test is simply too low to be informative. This direct test of the effect of voting on subsequent party choice can therefore not be used as support for cognitive dissonance theory in the context of elections.

When this test is applied to Swedish data, low power turns out again to be a problem. The estimated effect is seven percentage points, but it is not even close to being statistically significant and the confidence intervals include an equally large negative effect. ${ }^{23}$ As a result, this kind of test provides little information. The relevance of cognitive dissonance theory, in the context of elections, has, therefore, to be assessed by the indirect evidence provided by effects on political attitudes.

\section{Concluding Remarks}

This paper has investigated whether the act of voting influences attitudes toward political parties and candidates, which is a prediction from cognitive dissonance theory. To be able to assess if cognitive dissonance theory has implications for our understanding of elections, attitudes are measured just before elections, when citizens have the possibility to vote in the near future. In contrast to earlier studies, I find no evidence of dissonance induced attitude change. This finding is confirmed by analyzing a variety of political attitudes with data from both Sweden and the United States.

There are at least two plausible explanations for why no dissonance induced attitude change is found in this paper, while Mullainathan and Washington provide such evidence. First, it could be that citizens temporarily change their attitudes to be consistent with previous voting behavior. But, when the time to act upon these attitudes is coming, they admit to themselves that they were wrong (if they were) and regain unbiased attitudes and consequentially vote for another party. A second possibility is that dissonance induced

\footnotetext{
${ }^{23}$ Detailed results are available upon request.
} 
attitude change is taking place right after voting, and then slowly converge back to an unbiased point as time elapses. The two explanations predict different dynamic adjustments of attitudes. The present analysis can, however, not discriminate between them.

Regardless of which of the two explanations above that is correct, we have no reason to assume that voters would refrain from voting for another party if the circumstances motivate such a change. As a consequence, the argument that cognitive dissonance could provide a new explanation for the incumbency advantage, and a motivation for term limits, is not supported by the data. Similarly, the analyses herein do not support the claim that high turnout is inefficient. Instead, the results are more in line with a rational formation of political attitudes - at least at times when citizens are about to act upon their attitudes. 
Appendix A: Detailed Description of the Swedish Data

\section{A1. The Swedish Election Studies}

The Swedish National Data Service (SND) has made the data available for this paper. The data in the Swedish Election Studies were originally collected in a research project at the Department of Political Science at Göteborg University, under the guidance of Sören Holmberg, Henrik Oscarsson, and Mikael Gilljam. Neither SND nor the primary researchers are responsible for the analyses presented in this paper. The sample of the Swedish Election Studies is drawn from a population of 18 to 80 year old Swedish citizens entitled to vote in the general election. Swedes living abroad are not included in the sample. The Swedish Election Studies are available for research given that the project has passed an ethical vetting of research involving humans. ${ }^{24}$

\section{A2. Variables}

Attitude about the party of the Prime Minister: Explained in the text (5).

Attitude about Prime Minister: Explained in the text (6.3).

Party: 1 if the respondent prefers the party of the Prime Minister to any other party, 0 otherwise.

Second: 1 if the respondent was eligible to vote in the previous election, 0 otherwise.

Knowledgeable, Inspiring, and Likable: Explained in the text (6.3).

High school: 1 if the respondent has attended high school, 0 otherwise.

University: 1 if the respondent has attended education at the university level, 0 otherwise.

Cohabit: 1 if the respondent is married or cohabiting, 0 otherwise.

Male: 1 if respondent is male, 0 if female.

Age: Years of age

Urban: 1 if the respondent lives in a city (town), 0 otherwise.

Employed: 1 if the respondent is employed (part or full time), 0 otherwise.

Income: Category variable between 1 and 5 (1=low income, 5=high income).

Student: 1 if the respondent is a student, 0 otherwise.

Union: 1 if the respondent is a member of a union, 0 otherwise.

Homeowner: 1 if the respondent owns a home, 0 otherwise.

\footnotetext{
${ }^{24}$ For information on how to access the data contact either snd@snd.gu.se or the author.
} 


\section{A3. Summary Statistics}

Table A1: Descriptive Statistics for the Swedish Data (1979-2002)

\begin{tabular}{|c|c|c|c|}
\hline Variable & First time voters & $\begin{array}{l}\text { Second time } \\
\text { voters }\end{array}$ & $\begin{array}{l}\text { Sign. } \\
\text { Diff. }\end{array}$ \\
\hline Attitude toward the Prime & 5.50 & 5.40 & - \\
\hline Minister's party & $(5.21-5.76)$ & $(5.09-5.69)$ & \\
\hline Attitude toward the Prime & 5.28 & 5.07 & \\
\hline Minister & $(5.00-5.57)$ & $(4.77-5.37)$ & \\
\hline Knowledgeable & $\begin{array}{c}3.10 \\
(2.99-3.20)\end{array}$ & $\begin{array}{c}3.07 \\
(2.96-3.17)\end{array}$ & - \\
\hline Prime Minister: Inspiring & $\begin{array}{c}2.03 \\
(1.92-2.14)\end{array}$ & $\begin{array}{c}1.95 \\
(1.82-2.08)\end{array}$ & - \\
\hline Prime Minister: Likable & $\begin{array}{c}2.51 \\
(2.31-2.71)\end{array}$ & $\begin{array}{c}2.48 \\
(2.27-2.69)\end{array}$ & - \\
\hline Party & $\begin{array}{c}0.19 \\
(0.15-0.23)\end{array}$ & $\begin{array}{c}0.20 \\
(0.15-0.25)\end{array}$ & \\
\hline Age & $\begin{array}{c}19.8 \\
(19.77-19.92)\end{array}$ & $\begin{array}{c}21.8 \\
(22.70-21.84)\end{array}$ & $* * *$ \\
\hline Male & $\begin{array}{c}0.46 \\
(0.41-0.51)\end{array}$ & $\begin{array}{c}0.48 \\
(0.42-0.54)\end{array}$ & - \\
\hline Cohabit & $\begin{array}{c}0.19 \\
(0.15-0.23)\end{array}$ & $\begin{array}{c}0.37 \\
(0.32-0.43)\end{array}$ & $* * *$ \\
\hline High school & $\begin{array}{c}0.71 \\
(0.66-0.75)\end{array}$ & $\begin{array}{c}0.61 \\
(0.55-0.66)\end{array}$ & $* * *$ \\
\hline University & $\begin{array}{c}0.14 \\
(0.11-0.18)\end{array}$ & $\begin{array}{c}0.21 \\
(0.17-0.26)\end{array}$ & $* *$ \\
\hline Student & $\begin{array}{c}0.26 \\
(0.22-0.31)\end{array}$ & $\begin{array}{c}0.28 \\
(0.23-0.33)\end{array}$ & \\
\hline Employed & $\begin{array}{c}0.51 \\
(0.46-0.56)\end{array}$ & $\begin{array}{c}0.62 \\
(0.56-0.67)\end{array}$ & $* * *$ \\
\hline Union & $\begin{array}{c}0.43 \\
(0.39-0.49)\end{array}$ & $\begin{array}{c}0.61 \\
(0.56-0.67)\end{array}$ & $* * *$ \\
\hline Income ( 5 grade scale) & $\begin{array}{c}1.41 \\
(1.33-1.48)\end{array}$ & $\begin{array}{c}1.98 \\
(1.87-2.09)\end{array}$ & $* * *$ \\
\hline Urban & $\begin{array}{c}0.60 \\
(0.55-0.65)\end{array}$ & $\begin{array}{c}0.71 \\
(0.66-0.76)\end{array}$ & $* * *$ \\
\hline Home owner & $\begin{array}{c}0.36 \\
(0.31-0.41)\end{array}$ & $\begin{array}{c}0.25 \\
(0.20-0.30)\end{array}$ & $* * *$ \\
\hline Number of observations & 391 & 305 & \\
\hline
\end{tabular}

Notes: Means and $95 \%$ confidence intervals (in parentheses). ${ }^{*}$ significant at $10 \%$; ** significant at $5 \%$; *** significant at $1 \%$. 
Appendix B: Summary Statistics for the American Data

Table B1: Descriptive Statistics for the American Data (1980-2000)

\begin{tabular}{|c|c|c|c|}
\hline Variable & $\begin{array}{l}\text { First time } \\
\text { voters }\end{array}$ & $\begin{array}{l}\text { Second time } \\
\text { voters }\end{array}$ & Sign. Diff. \\
\hline Presidential thermometer & 59.4 & 55.1 & ** \\
\hline $\begin{array}{l}\text { (Range 0-100) } \\
\text { Party }\end{array}$ & $\begin{array}{c}(56.5-62.3) \\
0.45 \\
(0.39-0.51)\end{array}$ & $\begin{array}{c}(52.2-58.0) \\
0.40 \\
(0.35-0.46)\end{array}$ & \\
\hline Age & $\begin{array}{c}20.5 \\
(20.4 .-20.6)\end{array}$ & $\begin{array}{c}22.5 \\
(22.5-22.6)\end{array}$ & $* * *$ \\
\hline Male & $\begin{array}{c}0.41 \\
(0.35-0.47)\end{array}$ & $\begin{array}{c}0.48 \\
(0.43-0.54)\end{array}$ & * \\
\hline Married & $\begin{array}{c}0.24 \\
(0.19-0.29)\end{array}$ & $\begin{array}{c}0.36 \\
(0.31-0.42)\end{array}$ & $* * *$ \\
\hline High school & $\begin{array}{c}0.88 \\
(0.83-0.91)\end{array}$ & $\begin{array}{c}0.88 \\
(0.84-0.91)\end{array}$ & \\
\hline Income $(\log )$ & $\begin{array}{c}9.48 \\
(9.36-9.59)\end{array}$ & $\begin{array}{c}9.56 \\
(9.46-9.65)\end{array}$ & *** \\
\hline Employed & $\begin{array}{c}0.58 \\
(0.52-0.64)\end{array}$ & $\begin{array}{c}0.72 \\
(0.67-0.77)\end{array}$ & \\
\hline Union & $\begin{array}{c}0.13 \\
(0.09-0.17)\end{array}$ & $\begin{array}{c}0.16 \\
(0.12-0.20)\end{array}$ & \\
\hline Urban & $\begin{array}{c}0.34 \\
(0.29-0.40)\end{array}$ & $\begin{array}{c}0.25 \\
(0.21-0.30)\end{array}$ & $* *$ \\
\hline Home owner & $\begin{array}{c}0.37 \\
(0.32-0.43)\end{array}$ & $\begin{array}{c}0.39 \\
(0.33-0.44)\end{array}$ & \\
\hline Employed & $\begin{array}{c}0.58 \\
(0.52-0.64)\end{array}$ & $\begin{array}{c}0.72 \\
(0.67-0.77)\end{array}$ & \\
\hline Black & $\begin{array}{c}0.17 \\
(0.13-0.22)\end{array}$ & $\begin{array}{c}0.15 \\
(0.11-0.19)\end{array}$ & \\
\hline Hispanic & $\begin{array}{c}0.07 \\
(0.05-0.11)\end{array}$ & $\begin{array}{c}0.09 \\
(0.07-0.13)\end{array}$ & \\
\hline Asian & $\begin{array}{c}0.02 \\
(0.008-0.045)\end{array}$ & $\begin{array}{c}0.006 \\
(0.00-0.02)\end{array}$ & * \\
\hline Native & $\begin{array}{c}0.02 \\
(0.01-0.05)\end{array}$ & $\begin{array}{c}0.05 \\
(0.03-0.08)\end{array}$ & * \\
\hline Democrat & $\begin{array}{c}0.49 \\
(0.43-0.55)\end{array}$ & $\begin{array}{c}0.45 \\
(0.40-0.50)\end{array}$ & \\
\hline Republican & $\begin{array}{c}0.33 \\
(0.28-0.39)\end{array}$ & $\begin{array}{c}0.37 \\
(0.32-0.43)\end{array}$ & \\
\hline Independent & $\begin{array}{c}0.18 \\
(0.14-0.23)\end{array}$ & $\begin{array}{c}0.18 \\
(0.14-0.22)\end{array}$ & \\
\hline Number of observations & 287 & 345 & \\
\hline
\end{tabular}

Notes: Means and $95 \%$ confidence intervals (in parentheses). ${ }^{*}$ significant at $10 \%$; ** significant at $5 \%$; ** significant at $1 \%$. 
Appendix C: Detailed Regression Results

Table C1: Basic Results for Sweden (detailed reports related to Table 4)

Dependent variable: Attitude toward the party of the Prime Minister 1979-2002.

Age span

Second $\times$ Party

Second

Party

Control variables

Male

Cohabit

High School

University

Student

Employed

Income

Union

Urban

Homeowner

Age

Interactions

Male

Cohabit

High School

University

Student

Employed

Income

Union

Urban

Homeowner

Age

Year dummies

1979

1982

1985

1988

1991

1994

1998

2002

Observations
(1)

(2)

\section{9-22}

$-0.125$

(0.345)

$-0.213$

$(0.250)$

$3.641^{* * *}$

(0.237)

\section{$-0.071$}

$-0.578$

0.045

0.464

$-0.685$

0.576

$-0.486^{* *}$

$-0.100$

$0.726^{* *}$

$0.745^{*}$

$-0.082$

0.258

0.045

$-0.512$

0.320

$-1.040$

$0.619^{* *}$

$0.882^{*}$

$-0.729^{*}$

$-1.044^{* *}$

$4.299^{* * *}$

$4.636^{* *}$

$4.507^{* * *}$

$4.899^{* * *}$

$4.921^{* * *}$

$3.494^{* * *}$

$5.387^{*}$

$5.788^{* * *}$
18-23

$-0.115$

(0.279)

$-0.144$

(0.221)

$3.812^{* * *}$

(0.197)

0.154

$-0.504$

0.090

0.226

$-0.610$

0.101

$-0.323^{*}$

$-0.198$

$0.924^{* * * *}$

0.483

$-0.538$

0.251

0.035

$-0.452$

0.476

$-0.286$

0.345

$0.899^{* *}$

$-1.019^{* * *}$

$-0.611$

$4.541^{\text {*** }}$

$4.658^{* * *}$

$4.359^{* * *}$

$4.916^{* * *}$

$4.729^{* * *}$

$3.151^{\text {*** }}$

$5.194^{* * * *}$

$5.653^{* * *}$
(3)

19-22

$-0.029$

$(0.350)$

0.078

(0.348)

$3.590^{* * *}$

(0.240)

$-0.065$

$-0.603$

0.046

0.376

$-0.665$

0.546

$-0.523^{* *}$

$-0.108$

$0.693^{* *}$

$0.708^{*}$

$-0.024$

$-0.086$

0.346

0.049

$-0.314$

0.319

$-1.017$

$0.736^{* *}$

$0.930^{*}$

$-0.665$

$-1.029^{* * *}$

$-0.242$

4.805

5.179

$9.663^{* * *}$

$10.060^{* * *}$

$10.104^{* * *}$

4.031

$10.807^{* * *}$

$11.227^{* * *}$
(4)

18-23

$-0.018$

$(0.285)$

$-0.107$

(0.296)

$3.741^{\text {*** }}$

(0.201)

0.147

$-0.629^{*}$

0.056

0.022

$-0.512$

0.037

$-0.384^{* *}$

$-0.317$

$0.871^{* * *}$

0.441

0.156

$-0.523$

0.434

0.085

$-0.119$

0.325

$-0.241$

$0.478^{* * *}$

$1.076^{* *}$

$-0.925^{* *}$

$-0.589$

$-0.249^{*}$

556
1.652

1.830

$6.085^{* * *}$

$6.652^{*}$

$6.455^{* * *}$

0.227

$6.988^{* * *}$

$7.478^{* * *}$

Notes: Standard errors not reported. * significant at 10\%; ** significant at 5\%; $* * *$ significant at $1 \%$. 
Table C2: Robustness Results for the American Case (detailed reports related to Table 6) Dependent variable: Feelings toward the U.S. President 1980-2000.

(1)

\begin{tabular}{|c|c|c|c|c|}
\hline Second $\times$ Party & 1.849 & 2.218 & 1.717 & 2.511 \\
\hline Second & $-5.575^{* *}$ & $-4.303^{*}$ & -7.343 & $-7.491^{* *}$ \\
\hline Party & $20.922^{* * *}$ & $20.965^{* * *}$ & $20.958^{* * *}$ & $20.774^{* * *}$ \\
\hline \multicolumn{5}{|c|}{ Control variables } \\
\hline High school & -0.332 & -0.536 & -0.047 & -0.405 \\
\hline Income (log) & $-3.623^{*}$ & -2.661 & $-3.681^{*}$ & -2.663 \\
\hline Employed & 4.799 & 1.720 & 4.615 & 1.935 \\
\hline Married & $10.850^{* * *}$ & $5.425^{*}$ & $10.692^{* * *}$ & $5.574^{*}$ \\
\hline Urban & 0.759 & -1.918 & 0.752 & -2.063 \\
\hline Male & 0.715 & 1.355 & 0.703 & 1.406 \\
\hline Black & $18.963^{* * *}$ & $16.742^{* * *}$ & $18.868^{* * *}$ & $16.880^{* * *}$ \\
\hline Hispanic & $10.108^{* *}$ & $12.108^{* * *}$ & $10.194^{* *}$ & $12.288^{* * *}$ \\
\hline Asian & $12.183^{* *}$ & $9.703^{* *}$ & $12.404^{* *}$ & $9.721^{* *}$ \\
\hline Native & 1.446 & 2.365 & 1.591 & 2.684 \\
\hline Union & -6.378 & -5.290 & -6.453 & -5.384 \\
\hline Homeowner & $7.674^{* *}$ & 3.036 & $7.537^{* *}$ & 3.003 \\
\hline \multicolumn{5}{|c|}{ Interactions (republic) } \\
\hline High school & 1.587 & 1.741 & 1.204 & 1.461 \\
\hline Employed & $6.531^{* * *}$ & $5.222^{* *}$ & $6.534^{* * *}$ & $5.203^{* *}$ \\
\hline Married & -1.812 & 0.169 & -1.570 & -0.300 \\
\hline Urban & -5.884 & -2.046 & -5.775 & -2.733 \\
\hline Male & -5.955 & -3.304 & -6.040 & -3.339 \\
\hline Black & -2.739 & -2.457 & -2.712 & -2.579 \\
\hline Hispanic & $-30.355^{* * *}$ & $-27.954^{* * *}$ & $-30.268^{* * *}$ & $-28.144^{* * *}$ \\
\hline Asian & $-12.392^{*}$ & $-13.874^{* *}$ & $-12.354^{*}$ & $-13.800^{* *}$ \\
\hline Native & $-22.192^{* * *}$ & $-17.475^{* * *}$ & $-22.280^{* * *}$ & $-17.480^{* * *}$ \\
\hline Union & -1.326 & -6.254 & -1.355 & -6.284 \\
\hline Homeowner & 4.360 & 2.541 & 4.531 & 2.571 \\
\hline High school & -5.171 & 0.773 & -4.970 & 0.909 \\
\hline State dummies & Yes & Yes & Yes & Yes \\
\hline Year dummies & Yes & Yes & Yes & Yes \\
\hline Age & & & 1.234 & 0.618 \\
\hline Age interaction & & & -0.526 & 0.742 \\
\hline Observations & 632 & 901 & 632 & 901 \\
\hline
\end{tabular}

Notes: Standard errors not reported. $*$ significant at $10 \% ; * *$ significant at $5 \% ; * * *$ significant at $1 \%$. 


\section{References}

Akerlof, George A., and William T. Dickens. 1982. "The Economic Consequences of Cognitive Dissonance." American Economic Review, 72(3): 307-319.

Anderson, Christopher, Silvia Mendes, and Yuliya Tverdova. 2004. "Endogenous Economic Voting: Evidence from the 1997 British Election.” Electoral Studies, 23(4): 683-708.

Aronson, Elliot. 1968 "Dissonance Theory: Progress and Problems." In Theories of Cognitive Consistency: A Sourcebook, ed. Abelson, R.P., E. Aronson, W.J. McGuire, T.M. Newcomb, M.J.Rosenberg, and P.H. Tannenbaum, pp. 5-27. Chicago IL: Rand McNally.

Aronson, Elliot. 1992. "The Return of the Repressed: Dissonance Theory Makes a Comeback.” Psychological Inquiry, 3(4): 303-311.

Beasley, Ryan, and Mark Joslyn. 2001. "Cognitive Dissonance and Post-decision Attitude Change in Six Presidential Elections." Political Psychology, 22(3): 521-540.

Brehm, Jack. 1956. "Postdecision Changes in the Desirability of Alternatives." Journal of Abnormal and Social Psychology, 52(3): 384-389.

Chen, Keith. 2008. "Rationalization and Cognitive Dissonance: Do Choices Affect or Reflect Preferences? Cowles Foundation Discussion Paper No. 1669.

Cooper, Joel. 1980. "Reducing Fears and Increasing Assertiveness: The Role of Dissonance Reduction." Journal of Experimental Social Psychology, 16: 354-363.

Cooper, Joel. 2007. Cognitive Dissonance: Fifty Years of a Classic Theory. London, SAGE Publications Ltd.

Cooper, Joel, and Russell, H. Fazio. 1984. "A New Look at Dissonance Theory." In Advances in Experimental Psychology, ed. Berkowitz, L., vol. 17: 229-264. Orlando, FL: Academic Press.

Egan, Louisa C., Laurie R. Santos, and Paul Bloom. 2007. “The Origins of Cognitive Dissonance: Evidence from Children and Monkeys.” Psychological Science, 18(11): 978-983.

Festinger, Leon. 1957. A Theory of Cognitive Dissonance. Stanford, CA: Stanford University Press.

Festinger, Leon, Henry W. Riecken, and Stanley Schachter. 1964. When Prophecy Fails: A Social and Psychological Study of a Modern Group that Predicted the Destruction of the World. New York, NY, Harper Row.

Harmon-Jones, Eddie, and Judson Mills (eds). 1999. Cognitive Dissonance: Progress on a Pivotal Theory in Social Psychology. Washington, DC: American Psychological Association.

Holmberg, Sören, and Henrik Oscarsson. 2004. Väljare. Svenskt Väljarbeteende under 50 år. Stockholm, Nordstedts Juridik AB.

Masters, Julie. 2005. "A Midwestern Response to the Events of September 11, 2001." Journal of Loss and Trauma, 10(4): 369-381.

Mullainathan, Sendhil, and Ebonya Washington. 2009. "Sticking with Your Vote: Cognitive Dissonance and Political Attitudes. American Economic Journal - Applied Economics, 1(1): 86-111.

Stone, Jeff, Elliot Aronson, A. Lauren Crain, Matthew P. Winslow, and Carrie B. Fried. 1994. "Inducing Hypocrisy as a Means of Encouraging Young Adults to Use Condoms." Personality and Social Psychology Bulletin, 20: 116-128. 
WORKING PAPERS*

Editor: Nils Gottfries

2007:31 Ranjula Bali Swain and Maria Floro, Effect of Microfinance on Vulnerability, Poverty and Risk in Low Income Households. 35pp.

2008:1 Mikael Carlsson, Johan Lyhagen and Pär Österholm, Testing for Purchasing Power Parity in Cointegrated Panels. 20pp.

2008:2 Che-Yuan Liang, Collective Lobbying in Politics: Theory and Empirical Evidence from Sweden. 37pp.

2008:3 Spencer Dale, Athanasios Orphanides and Pär Österholm, Imperfect Central Bank Communication: Information versus Distraction. 33pp.

2008:4 Matz Dahlberg and Eva Mörk, Is there an election cycle in public employment? Separating time effects from election year effects. 29pp.

2008:5 Ranjula Bali Swain and Adel Varghese, Does Self Help Group Participation Lead to Asset Creation. 25pp.

2008:6 Niklas Bengtsson, Do Protestant Aid Organizations Aid Protestants Only? 28pp.

2008:7 Mikael Elinder, Henrik Jordahl and Panu Poutvaara, Selfish and Prospective Theory and Evidence of Pocketbook Voting. 31pp.

2008:8 Erik Glans, The effect of changes in the replacement rate on partial retirement in Sweden. 30pp.

2008:9 Erik Glans, Retirement patterns during the Swedish pension reform. 44pp.

2008:10 Stefan Eriksson and Jonas Lageström, The Labor Market Consequences of Gender Differences in Job Search. 16pp.

2008:11 Ranjula Bali Swain and Fan Yang Wallentin, Economic or Non-Economic Factors - What Empowers Women?. 34pp.

2008:12 Matz Dahlberg, Heléne Lundqvist and Eva Mörk, Intergovernmental Grants and Bureaucratic Power. 34pp.

2008:13 Matz Dahlberg, Kajsa Johansson and Eva Mörk, On mandatory activation of welfare receivers. $39 \mathrm{pp}$.

2008:14 Magnus Gustavsson, A Longitudinal Analysis of Within-Education-Group Earnings Inequality. 26pp.

2008:15 Henrique S. Basso, Delegation, Time Inconsistency and Sustainable Equilibrium. 24pp.

\footnotetext{
* A list of papers in this series from earlier years will be sent on request by the department.
} 
2008:16 Sören Blomquist and Håkan Selin, Hourly Wage Rate and Taxable Labor Income Responsiveness to Changes in Marginal Tax Rates. $31 \mathrm{pp}$.

2008:17 Jie Chen and Aiyong Zhu, The relationship between housing investment and economic growth in China : A panel analysis using quarterly provincial data. $26 \mathrm{pp}$.

2009:1 Per Engström, Patrik Hesselius and Bertil Holmlund, Vacancy Referrals, Job Search, and the Duration of Unemployment: A Randomized Experiment. $25 \mathrm{pp}$.

2009:2 Chuan-Zhong Li and Gunnar Isacsson, Valuing urban accessibility and air quality in Sweden: A regional welfare analysis. 24pp.

2009:3 Luca Micheletto, Optimal nonlinear redistributive taxation and public good provision in an economy with Veblen effects. $26 \mathrm{pp}$.

2009:4 Håkan Selin, The Rise in Female Employment and the Role of Tax Incentives. An Empirical Analysis of the Swedish Individual Tax Reform of $1971.38 \mathrm{pp}$.

2009:5 Lars M. Johansson and Jan Pettersson, Tied Aid, Trade-Facilitating Aid or Trade-Diverting Aid? 47pp.

2009:6 Håkan Selin, Marginal tax rates and tax-favoured pension savings of the selfemployed Evidence from Sweden. 32pp.

2009:7 Tobias Lindhe and Jan Södersten, Dividend taxation, share repurchases and the equity trap. $27 \mathrm{pp}$.

2009:8 Che-Yuan Liang, Nonparametric Structural Estimation of Labor Supply in the Presence of Censoring. 48pp.

2009:9 Bertil Holmlund, Incentives in Business and Academia. 12pp.

2009:10 Jakob Winstrand, The Effects of a Refinery on Property Values - The Case of Sweden. 27pp.

2009:11 Ranjula Bali Swain and Adel Varghese. The Impact of Skill Development and Human Capital Training on Self Help Groups. 28pp.

2009:12 Mikael Elinder. Correcting Mistakes: Cognitive Dissonance and Political Attitudes in Sweden and the United States. 25 pp.

See also working papers published by the Office of Labour Market Policy Evaluation http://www.ifau.se/ 